\title{
Partial Endonuclease Digestion Mapping of Restriction Sites Using PCR-amplified DNA
}

\author{
Juan Carlos Morales, ${ }^{1,3}$ John C. Patton, ${ }^{2}$ and John W. Bickham ${ }^{1}$
}

${ }^{1}$ Department of Wildlife and Fisheries Sciences, Texas A\&M University, College Station, Texas $77843 ;{ }^{2}$ LGL Ecological Research Associates Inc., Bryan, Texas 77801

\begin{abstract}
Although direct DNA sequencing is now readily available, restriction enzyme analyses are still widely used in population genetics and molecular systematics studies. These analyses provide cheaper and faster ways to assay patterns of nucleotide differentiation across a large number of individuals. In this paper, we introduce a new approach to restriction enzyme analyses in which high-resolution restriction site maps are obtained from partial digestions of PCR products. This procedure increases the level of resolution at least an order of magnitude over the double-digestion method for restriction enzyme mapping, can target specific DNA regions with the use of specific primers, and, because it uses chemiluminescent detection of DNA, can be easily implemented in laboratories that lack the necessary setups to handle radioactive substances.
\end{abstract}

$\mathrm{n}$ just a few years, DNA analyses have become the method of choice in the investigation of population genetics and systematics. Analysis of DNA has several significant advantages for population genetics and evolutionary studies, including the fact that the genotype rather than the phenotype is assayed. ${ }^{(1)}$ Of the several approaches for the analysis of DNA, the most widely used methodologies in organismic biology include restriction endonuclease analyses and direct sequencing of particular DNA regions. Direct sequencing obviously conveys the ultimate level of resolution of nucleotide differentiation. However, current techniques available for sequencing are rather cumbersome and relatively expensive for most applications of population genetics and evolutionary studies, where a great number of individuals have to be assayed. ${ }^{(1)}$ Restriction endonuclease analyses provide a cheaper and faster way to assay greater numbers of individuals. However, the most commonly used detection systems in restriction endonuclease analyses, end labeling, or transfer hybridization require either vast amounts of highquality purified target DNA or a laborious probing procedure that is not particularly effective with restriction enzymes having a high frequency of cleavage sites in the target DNA. ${ }^{(2,3)}$

Once the restriction fragments are visualized, two approaches typically are used in the analysis of DNA restriction data, the comparison of fragments, and the comparison of sites. Fragment comparison assumes that fragments of identical size must share flanking cleavage sites, which is generally true for sequences from closely related individu- als. ${ }^{(3)}$ However, as sequence divergence increases, the likelihood of fragments of the same size produced by different cleavage sites also increases, and this can have a detrimental effect on the data analysis. ${ }^{(4,5)}$

Restriction site mapping eliminates the problem of convergent fragment lengths. Two methods normally used for restriction site mapping include the double-digestion method and the comparison of fragment patterns to a known sequence. The double-digestion method compares the fragment patterns produced by two restriction enzymes independently, and then concurrently, to produce an estimation of the relative position of the cleavage sites. ${ }^{(3)}$ This procedure requires considerable patience and is very sensitive to errors in the estimation of fragment lengths associated with gel electrophoresis. Comparison of restriction fragments to a known sequence can be used to produce a higher-resolution map, ${ }^{(6)}$ but this method is by necessity confined to closely related individuals and it has the drawback of having to sequence the DNA molecule of interest in at least one individual.

Another approach for fine-structure restriction site mapping involves partial endonuclease digestion mapping. In this procedure, a DNA fragment labeled at one end is subjected to partial cleavage by a particular restriction enzyme. Visualization of the labeled fragments in a polyacrylamide or agarose gel enables the investigator to measure directly the distance of the restriction sites from the labeled end, but, unlike restriction mapping by double digestion, the analysis is not complicated by the presence of numerous cleavage sites for a given enzyme. $^{(7)}$
Present address: Genetics Laboratory, Department of Anthropology, 452 Schermerhorn Hall, Columbia University, New York, NY 10027. 
In this paper, we present a new approach for partial endonuclease digestion mapping, in which the DNA sequences analyzed are generated in vitro by the PCR. ${ }^{(8)}$ This approach was first advanced by J.C. Patton in an article by Cherfas. ${ }^{(9)}$ Using this procedure, a target DNA sequence is amplified by the addition of oligonucleotide primers complimentary to opposite strands of the target DNA. The development of universal primers, which recognize conserved DNA regions across a broad spectrum of taxa, allows for the analysis of the same target sequence among phylogenetically divergent forms. ${ }^{(10)}$ Primer specificity obviates the necessity of tedious purification procedures of suitable DNA. Moreover, the PCR procedure allows for the analysis of virtually any recoverable piece of DNA, including suboptimal samples. ${ }^{(11)}$

The main advantage of using PCR for partial endonuclease digestion mapping is that the critical one-side end-labeling step can be accomplished by the addition of one labeled primer during the amplification process. Primer labeling can be accomplished by the addition of ${ }^{32} \mathrm{P}$ to the $5^{\prime}$ end of the primer using $\mathrm{T} 4$ polynucleotide kinase or by the use of biotinylated primers, which can be obtained commercially. Biotinylated primers can be utilized in chemiluminescent detection of DNA. ${ }^{(12)}$ Both approaches have been implemented successfully in mapping attempts in our laboratory. However, the advantage of using biotinylated primers is that DNA analysis can be implemented in laboratories that lack the capability to handle radioactive substances. Biotinylated primers also can be stored for a long time without degradation. This paper details the procedure for nonradioactive, partial endonuclease digestion mapping of specific DNA sequences obtained through PCR amplifications using biotinylated primers.

The basic procedure is as follows: Segments of about 2000 bp in length are amplified with specific primers for the desired target DNA, and such segments are subjected to complete digestion with various restriction enzymes. Because the PCR technique allows for virtually an unlimited supply of sample DNA, the type and number of restriction enzymes that can be used depends only on the objectives of the research. The fragment patterns obtained from the complete digestion are visualized in agarose gels with ethidium bromide. Several individuals can be scored this way in a relatively short period. Once each of the variable haplotypes is identified for every enzyme, the next step is the partial digestion mapping of the cleavage sites. As with other mapping procedures, only one individual per variable haplotype is needed for the mapping procedure. For the partial endonuclease digestion mapping, target DNA sequences are reamplified, but this time with one of the primers labeled with biotin. This segment is partially digested with a restriction enzyme, and the resulting fragments are electrophoretically separated in an agarose gel using a DNA size standard to estimate fragment lengths. DNA fragments are transferred onto a nylon membrane with standard blotting procedures, and the immobilized DNA is detected by chemiluminescence using a Streptavidin-alkaline phosphatase (SA-AP) conjugate and a substrate (PPD) that luminesces when dephosphorylated. Both conjugate and substrate are available commercially from GIBCO-BRL. The SAAP conjugate binds to the biotin molecule attached to one of the primers, and the phosphatase dephosphorylates the substrate, resulting in light emission. This provides enough signal to expose a standard X-ray film normally used for autoradiography. Only those fragments with a biotin molecule attached to the primer position are visualized. The length of the fragments observed is a direct measure from the restriction site to the labeled primer position. This procedure has been applied successfully in a study of the systematic relationships of bats of the genus Lasiurus based on mitochondrial (mt) DNA sequences, ${ }^{(13)}$ and the data set from that study is used as a reference to explain the details of the mapping procedure.

Total DNA preparations were obtained from frozen and alcohol-preserved tissues by standard phenol/ chloroform extractions and ethanol precipitation procedures. ${ }^{(14)}$ Primer sets were selected to amplify segments of about 2000 bp of the mtDNA molecule. Although it is possible to amplify fragments longer than $2000 \mathrm{bp}$, we have observed that this length is optimal for the amplification of sequences from a wide array of different taxa, without any special modifications in a regular PCR protocol. ${ }^{(8)}$ The fragment patterns obtained in a regular digestion reaction are easily scored in agarose gels stained with ethidium bromide (Fig. 1a).

\section{MATERIALS AND METHODS Polymerase Chain Reaction}

Amplifications were performed according to the manufacturer's instructions either with AmpliTaq (GeneAmp, PerkinElmer Cetus) or Promega Taq DNA polymerase (Promega). Reactions of 100 $\mu l$ were performed using the buffer systems provided by the suppliers, $1 \mathrm{~mm}$ of each dNTP, and $10 \mu \mathrm{l}$ of each primer at a working concentration of $2 \mathrm{pm} / \mu \mathrm{l}$. $\mathrm{MgCl}_{2}$ concentrations ranged from 5 to $7.5 \mathrm{~mm}$. Genomic DNA added to each reaction was estimated from 10 to $1000 \mathrm{ng}$ per reaction. We have obtained consistent results utilizing $2 \mu \mathrm{l}$ of a genomic DNA solution obtained through standard phenol/chloroform extractions of DNA from nanogram amounts of fresh tissue resuspended in $75-100 \mu \mathrm{l}$ of $\mathrm{ddH}_{2} \mathrm{O}$ after the ethanol precipitation. Each $100-\mu \mathrm{l}$ amplification reaction yields enough template to assay from 15 to 18 restriction enzymes per individual. The amplification reactions were performed in a thermal cycler (PerkinElmer Cetus) with a denaturing temperature of $95^{\circ} \mathrm{C}$ for $50 \mathrm{sec}$, annealing temperature of $50-55^{\circ} \mathrm{C}$ for $35 \mathrm{sec}$, and extension temperature of $72^{\circ} \mathrm{C}$ for $2 \mathrm{~min}$, $30 \mathrm{sec}$, for $30-40$ cycles.

\section{Complete Digestion of Amplified Fragments}

The first approximation in this restriction endonuclease analysis is to score all the samples for patterns of variation, performing complete digestions to obtain a haplotype profile for the organisms under study. Restriction digests were performed with several restriction endonucleases following the specifications of the suppliers (GIBCO-BRL, New England BioLabs). Digestion reactions were accomplished in $25 \mu$ l total volume with 3 units of enzyme and $5 \mu$ l of the amplified mixture. Electrophoresis of the restriction digests was done in 1.5$1.75 \%$ agarose gels and the fragment patterns visualized by staining with ethidium bromide (Fig. 1a).

\section{Partial Digestion of Amplified Segments}

Once representative individuals were se- 

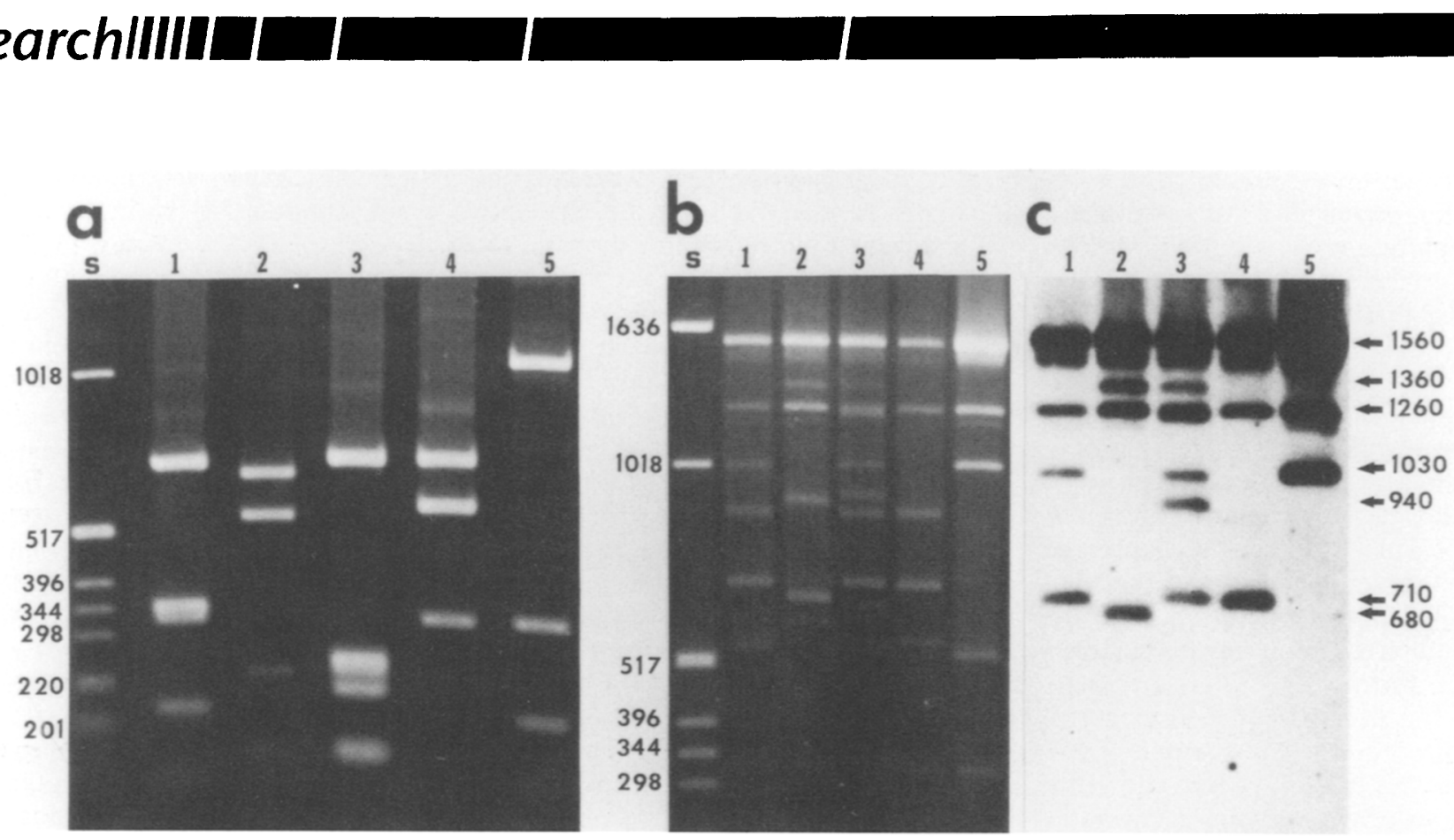

FIGURE 1 Example of the mapping procedure for a 1.6-kb segment on the 12S, 16S mtDNA region of species of tree bats restricted with the endonuclease AseI. The taxa shown are Lasiurus borealis (lane 1), L. seminolus (lane 2), L. pfeifferi (lane 3), L. blossevillii frantzi (lane 4 ), and $L$. blossevillii blossevillii (lane 5). (a). Complete digestion stained with ethidium bromide. (b). Partial digestion also stained with ethidium bromide. (c). Partial digestion after chemiluminescent detection of one-sided biotinylated fragments. The estimated fragment lengths correspond to the site positions with respect to the labeled primer. The broad band at $1560 \mathrm{bp}$ is an artifact due to some drag effect and the strong chemiluminescent reaction of the undigested fragment in this particular case.

lected for the mapping process, biotinlabeled segments were obtained following the same standard amplification procedures but with one of the primers biotinylated. The biotin complex attached to the $5^{\prime}$ end of the primer has no effect on the amplification procedure or any of the subsequent reactions.

One critical step at this stage was to ensure a partial digest that results in a homogeneous distribution of all the different fragment combinations. This was accomplished by doing an assay for each of the restriction enzymes at different unit concentrations by serial dilutions ${ }^{(7)}$ from 3 to 0.1875 units per reaction. For this assay, all the reactions were conducted in $25 \mu$ l total volumes for exactly $30 \mathrm{~min}$ and stopped by adding $5 \mu \mathrm{l}$ of 0.2 M EDTA.2Na. Table 1 shows the optimal enzyme concentrations for 26 enzymes used in a survey of the bat genus Lasiurus. It is important to notice that these parameters were obtained in our laboratory for the restriction enzymes provided by the specified supplier, and might differ in different laboratory setups or with enzymes from different suppliers. On the other hand, we have observed that these parameters remain fairly constant across different segments of the mtDNA or different taxa, as long as we use the same enzyme brands. Once the proper reaction conditions have been identified, the next step is to proceed with the partial digestion of the desired haplotypes to be mapped.

We have observed that although the scan provides the optimal enzyme concentrations for a particular set of samples, enough intersample variation might exist as to affect the quality of the partial digest in some individuals. To overcome this problem, we routinely do a set of two partial digestion reactions per sample, one at the higher end of the proper enzymatic conditions, and one at the lower end (according to the range specified in Table 1). Both samples are then combined in the same well during the electrophoresis run. This also helps to minimize the impact of the fact that some restriction sites are sometimes cleaved better than others. ${ }^{(7)}$ The most expeditious way to accomplish this for each sample is to add $5 \mu \mathrm{l}$ of DNA template in two reaction vials, make a master mix with all the other chemicals (including the enzyme at the higher concentration of the optimal range) for twice the amount of samples, take half of this master mix, and make a second mix in which the enzyme concentration is diluted in half by adding the same vol- ume of buffer with no enzyme. Twenty microliters of the proper mix are aliquoted to both sets of samples, and the reactions are incubated at the proper temperature for $30 \mathrm{~min}$. The reactions are stopped with EDTA, and, finally, both reactions per sample are combined into the same well in the agarose gel.

Samples were electrophoresed in $1.75-2 \%$ agarose gels for about $2 \mathrm{hr}$ at $200 \mathrm{~mA}$, stained with ethidium bromide, and photographed (Fig. 1b). A known size standard was used to estimate fragment lengths. If a biotinylated size standard is not available, then a ruler should be photographed next to the gel for future reference.

\section{Chemiluminescent Detection of Biotinylated Fragments}

For this step, we used the Photogene Nucleic Acid Detection System (Cat. No. 8192SA from GIBCO-BRL). The following protocol follows the one included in the instruction manual of the kit, but with some modifications to account for the fact that the kit is intended for chemiluminescent detection of DNA using hybridized biotinylated probes.

DNA fragments were blotted onto Photogene Nylon membranes as follows: 
TABLE 1 Optimal Enzyme Concentrations in Units per Reaction for Partial Digestions of Amplified Segments (about 2000 bp in length), in a Study of mtDNA Genes

\begin{tabular}{lc}
\hline Restriction & $\begin{array}{l}\text { Optimal } \\
\text { concentration } \\
\text { (units/reaction) }\end{array}$ \\
\hline enzyme & $1.5-0.75$ \\
Acc I (NEB) & $3.0-1.5$ \\
Aci I (NEB) & $3.0-1.5$ \\
Alu I (NEB) & $0.375-0.1875$ \\
Ase I (NEB) & $0.375-0.1875$ \\
Ava II (NEB) & $1.5-0.75$ \\
BsaA I (NEB) & $1.5-0.75$ \\
Bsa I (NEB) & $0.375-0.1875$ \\
BsmA I (NEB) & $0.375-0.1875$ \\
Bsp1286 I (NEB) & $0.375-0.1875$ \\
Bsr I (NEB) & $0.75-0.375$ \\
BstN I (NEB) & $3.0-1.5$ \\
BstU I (NEB) & $0.375-0.1875$ \\
Dde I (NEB) & $1.5-0.75$ \\
Dra I (BRL) & $3.0-1.5$ \\
Hae III (NEB) & $0.75-0.375$ \\
Hha I (BRL) & $0.75-0.375$ \\
Hinf I (NEB) & $0.375-0.1875$ \\
Hph I (NEB) & $0.375-0.1875$ \\
Mbo I (NEB) & $0.375-0.1875$ \\
Mbo II (BRL) & $1.5-0.75$ \\
Nla IV (NEB) & $3.0-1.5$ \\
Rma I (NEB) & $0.75-0.375$ \\
Rsa I (NEB) & $0.375-0.1875$ \\
Sau96 I (BRL) & $3.0-1.5$ \\
Ssp I (NEB) & $3.0-1.5$ \\
Taq I (BRL) & \\
\hline Requires 90 min of & \\
\hline
\end{tabular}

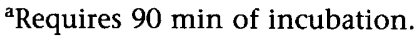

Incubation time $=30 \mathrm{~min}$. (NEB) Enzymes supplied by New England BioLabs; (BRL) enzymes supplied by GIBCO-BRL.

Gels were depurinated for no more than $15 \mathrm{~min}$ in $0.25 \mathrm{M} \mathrm{HCl}$, placed in denaturing solution $(1.5 \mathrm{M} \mathrm{NaCl}, 0.5 \mathrm{M} \mathrm{NaOH})$ twice for $20 \mathrm{~min}$, and placed in neutralizing solution $(1.0 \mathrm{M}$ Tris, $1.5 \mathrm{M} \mathrm{NaCl}, \mathrm{pH}$ 7.5) twice for $20 \mathrm{~min}$. Nylon membranes were soaked in $10 \times$ SSC $(1 \times$ SSC is 0.15 $\mathrm{M} \mathrm{NaCl}, 0.015$ м sodium citrate, $\mathrm{pH} 7.0$ ) for $15 \mathrm{~min}$, prior to blotting. Standard capillary Southern blots were performed overnight. After this step, the membrane is washed once for $5 \mathrm{~min}$, in $5 \times \mathrm{SSC}$, and baked at $80^{\circ} \mathrm{C}$ for $2 \mathrm{hr}$. The membranes can then be stored at room temperature for later use.

Next we prehybridized the nylon membrane in plastic hybridization bags with $250 \mu \mathrm{l} / \mathrm{cm}^{2}$ of prehybridization solution for $1 \mathrm{hr}$ at $42^{\circ} \mathrm{C}$. The prehybridization solution consists of $50 \%(\mathrm{wt} / \mathrm{vol})$ formamide, $0.9 \mathrm{M} \mathrm{NaCl}, 60 \mathrm{~mm}$ sodium phosphate ( $\mathrm{pH} 7.4), 0.1 \%$ (wt/vol) bovine serum albumin, $0.1 \%$ (wt/vol) Ficoll, $0.1 \%$ (wt/vol) polyvinylpyrrodoline, $1 \%$ (wt/vol) sodium dodecyl sulfate (SDS), and $200 \mu \mathrm{g} / \mathrm{ml}$ sheared salmon DNA. This step helps to increase significantly the signal-to-noise ratio in the chemiluminescent reaction. The membrane was then washed in $5 \times$ SSC, $0.5 \%$ (wt/vol) SDS for $30 \mathrm{~min}$ at $50^{\circ} \mathrm{C}$, and with $2 \times$ SSC for $5 \mathrm{~min}$ at room temperature.

The membrane was blocked for $1 \mathrm{hr}$ at $65^{\circ} \mathrm{C}$ in $0.75 \mathrm{ml} / \mathrm{cm}^{2}$ of blocking solution (Tris $100 \mathrm{~mm}, \mathrm{NaCl} 150 \mathrm{~mm}$, Tween $200.05 \%$ [vol/vol], bovine serum albu$\min 3 \%[w t / v o l])$. Next, $3.5 \mu \mathrm{l}$ of the streptavidin-alkaline phosphatase conjugate (SA-AP) per $100 \mathrm{~cm}^{2}$ was added in a 1:2000 dilution in TBS-Tween 20 (same as blocking solution but without albu- min), and incubated at room temperature for $10 \mathrm{~min}$. The membrane was then washed twice for $15 \mathrm{~min}$ in TBS-Tween 20 to wash the excess SA-AP conjugate, and placed in a final wash provided by the supplier for $1 \mathrm{hr}$ at room temperature. The membrane was blotted dry with filter papers and $0.01 \mathrm{ml} / \mathrm{cm}^{2}$ of the phosphatase substrate (PPD, provided in the detection kit) was added. Finally, the membrane was sealed between plastic sheets and ready for exposure (the supplier recommends waiting for about $3 \mathrm{hr}$ before exposure to allow the reaction to attain maximum strength). The light reaction was detected in Kodak X-OMAT film with exposure times from 5 to 15 min (Fig. 1c). Figure 1 shows an example of the basic steps of the mapping procedure with the enzyme Ase I for four species of Lasiurus.

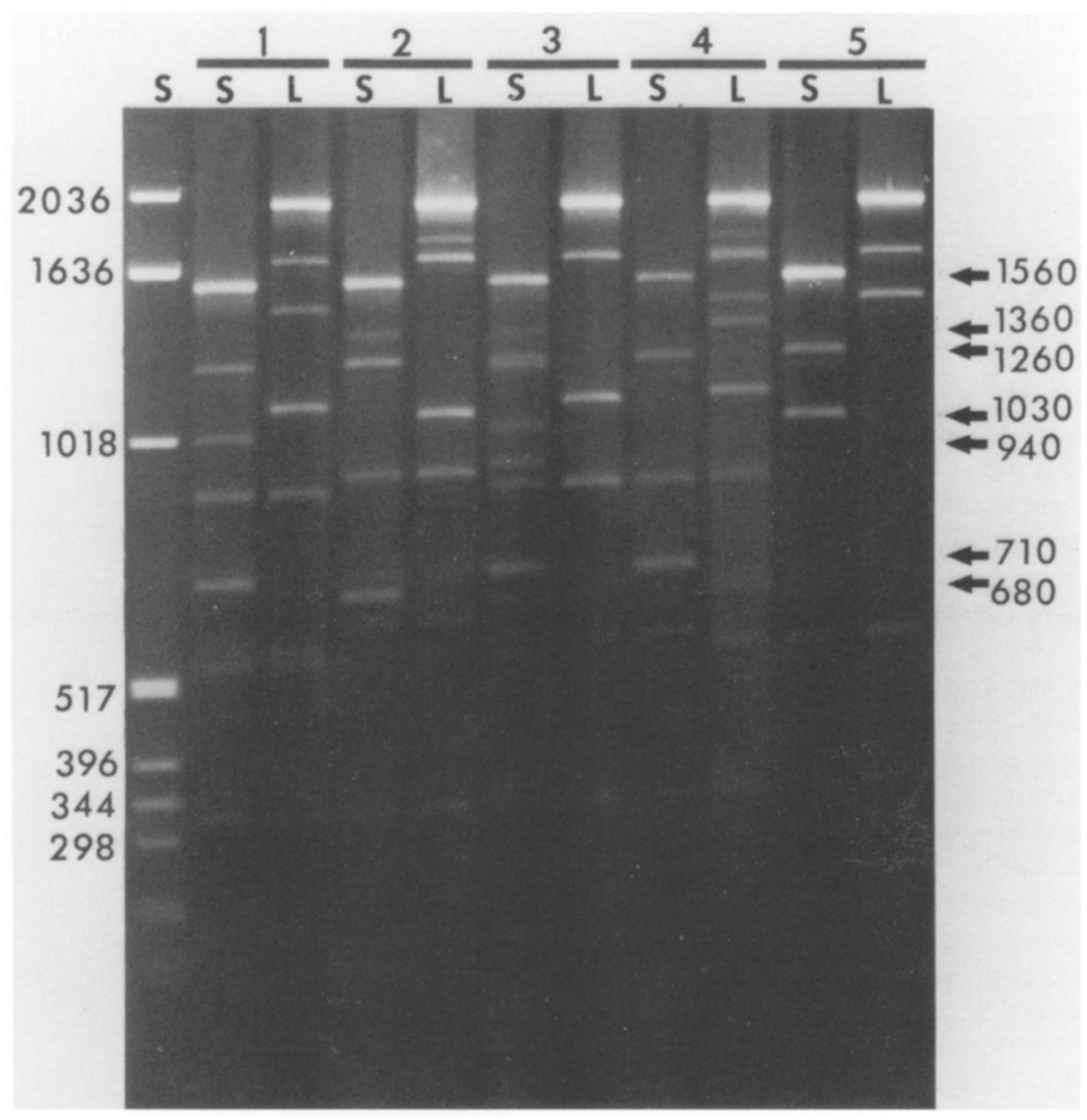

FICURE 2 Example of PEDM using two amplifications of differing length of the same target DNA sequence in the $12 \mathrm{~S}, 16 \mathrm{~S}$ ribosomal mtDNA region for four species of Lasiurus digested with the restriction enzyme AseI. The taxa are the same as in Fig. 1. (Lanes $S$ ) Short segment amplification; (lanes $L$ ) long segment amplification. Unmatched bands between the two lanes for the same individuals represent those fragments extending from the primer position to the cleavage site, which correspond to the same fragments visualized in Fig. 1c. 


\section{One-sided End-labeling by Alteration of the Size of the PCR Fragments}

In some cases, when the number of cleavage sites is rather small (1-4 sites), an interesting and fast approach to partial digestion mapping is to amplify the segment of interest twice, but with two primer sets so that one end of the segment is extended further in one of the amplifications. That is, one primer is used in both amplifications to define one end of the fragment, and two different primers, which are 100-200 bp away from each other, are used for the other end. The one-sided labeling for the partial digestion mapping will be the length of the fragment itself. After a partial digest, both samples are run side by side in an agarose gel and stained with ethidium bromide. The fragments that do not match in their mobilities in the two lanes represent the one-side labeled fragments (Fig. 2). The cleavage sites are then mapped with respect to the primer responsible for the shorter segment by measuring the length of the unmatched fragments in the partial digest of this segment, with respect to the fragments produced in the longer segment.

\section{RESULTS AND DISCUSSION}

Partial endonuclease digestion mapping has been applied successfully in a wide array of vertebrate taxa. In a study of several species of the genus Lasiurus, ${ }^{(13)} 135$ sites were mapped for different haplotypes for one segment in the $12 \mathrm{~S}$ and $16 \mathrm{~S}$ ribosomal mtDNA genes that was about $1560 \mathrm{bp}$ in length. This represents an equivalent of 625 nucleotides assayed for this region, or approximately $40 \%$ of the sequence. Using the same crude numerical approximation, a study of say 100 restriction sites mapped onto a regular vertebrate mtDNA molecule (which is a rather good achievement) represents only about $3.75 \%$ of the molecule sequence. Zink, ${ }^{(15)}$ in a study of mtDNA variation in sparrows based on fragment patterns, estimates that about $4.7 \%$ of the molecule was assayed. These data might be overestimations of the actual number of nucleotides assayed in any particular study, but they demonstrate that partial digestion mapping has the potential of providing more information than traditional double-digestion experiments. Moreover, partial digestion map- ping can be more accurate than doubledigestion mapping because the site positions are just read off from the gel. There is no need to puzzle with different fragment combinations to come up with the most likely site positions. The use of specific primers for a particular sequence has the added advantage of targeting useful regions of the genome for a particular purpose.

To stress further the importance of comparing mapped sites instead of just fragment patterns, a scattergram was produced comparing 496 different divergence estimates obtained from site and fragment data in the aforementioned study of the genus Lasiurus (Fig. 3). The restriction site matrix and the divergence value matrix of such a study can be consulted in Morales. ${ }^{(13)}$ As is evident from the plot, at low levels of divergence there is fairly good correspondence between estimates from fragment data and site data, with up to about $8 \%$ divergence estimated from site data (equal to about $4 \%$ from fragment data). Beyond that level, the correlation becomes rather loose as can be seen in the scattergram, and, although the correlation coefficient $(r)$ is rather high between the two matrices (0.87), a Mantel $Z$ statistics test based on 1000 random permutations indicated that these two matrices are significantly different $(p=0.001)$, which is expected because distance estimates from fragment data have a larger variance. ${ }^{(16)} \mathrm{Be}-$ sides, although at low levels of divergence the correlation is almost linear, it is important to notice that fragment data consistently resulted in lower divergence estimates than site data, as can be seen in the different scales between the two axes, even below the 0.05 level. This is interesting, because it has been suggested that fragment and site data divergence estimates should coincide at low levels of divergence.

Estimates of the evolutionary rate of the mtDNA ribosomal genes (12S and $16 S$ ) in the genus Lasiurus based on this high-resolution mapping procedure resulted in an evolutionary rate of $0.87 \%$ divergence per 1 million years, which is comparable to the range of divergence evolutionary rates observed among other mammalian groups for the $12 \mathrm{~S}$ ribosomal gene on the basis of sequence data. ${ }^{(17)}$ These results suggest that high-resolution restriction endonuclease mapping of specific regions may provide a level of resolution comparable to sequence data, or at least much more accurate than double-digestion mapping procedures of few enzymes on the entire mtDNA molecule, for the estimation of divergence values.

The additional processing steps required for the chemiluminescent detection could be considered the main disadvantage of this method. However, this additional amount of work becomes negligible if several membranes are pro-

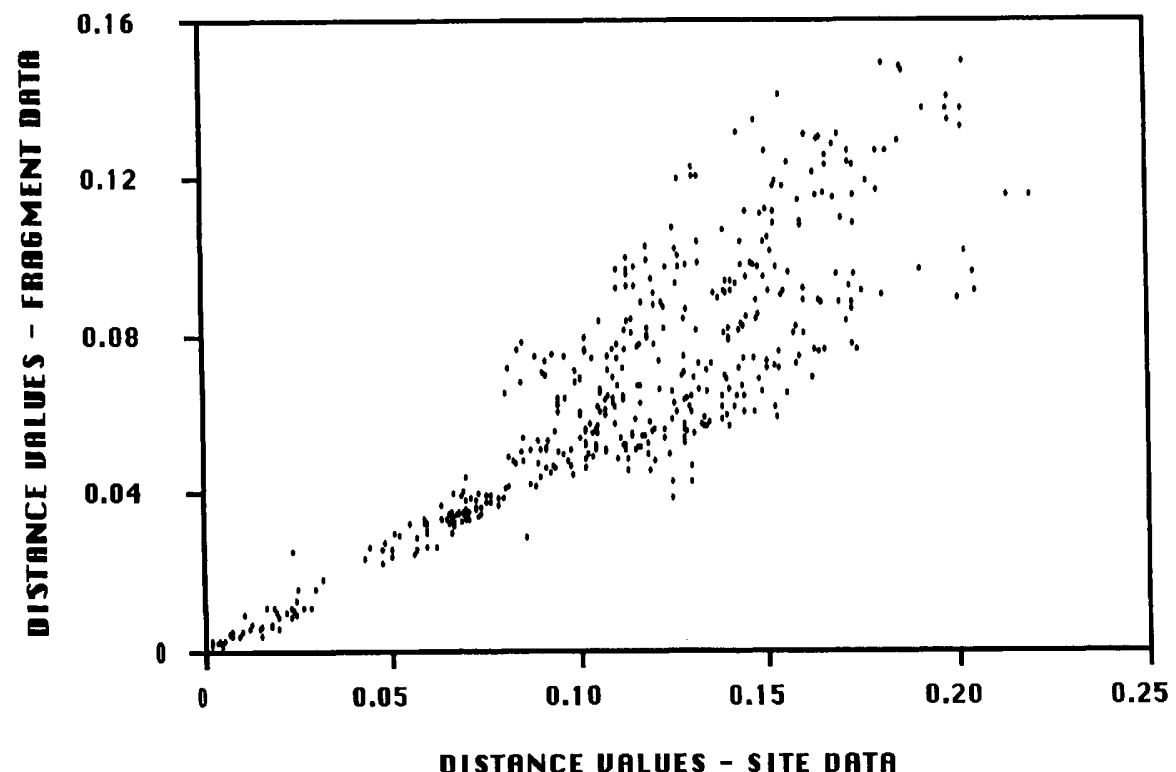

FIGURE 3 Scattergram comparing divergence estimates obtained from mapped site data and fragment data among 32 different haplotypes obtained in a study of the genus Lasiurus. ${ }^{(13)}$ 
cessed simultaneously. ${ }^{(12)}$ We believe that this method could become a standard procedure in studies of natural populations that demand an increase in both the number of samples assayed and the accuracy of the data obtained, without becoming prohibitively expensive or time consuming. By the same token, this method could be easily implemented in laboratories that cannot afford the elaborate setups necessary for other more standard methods of DNA analysis, specially in developing countries.

\section{ACKNOWLEDGMENTS}

We thank R. L. Honeycutt, S. K. Davis, and D. J. Schmidly for critical comments. This work was supported in part with Expanded Research Area funds through the Texas Agricultural Experiment Station, and by BP Exploration, Alaska, Inc. and the North Slope Burrough.

\section{REFERENCES}

1. Hillis, D. M. and C. Moritz. 1990. An overview of applications of molecular systematics. In Molecular systematics (ed. D.M. Hillis and C. Moritz), pp. 502-515. Sinauer Associates, Sunderland, Massachusetts.

2. Carr, S.M. and O.M. Griffith. 1987. Rapid isolation of animal mitochondrial DNA in a small fixed-angle rotor at ultrahigh speed. Biochem. Genet. 25: 385-390.

3. Dowling, T.E., C. Moritz, and J. D. Palmer. 1990. Nucleic acids II: Restriction site analysis. In Molecular systematics (ed. D.M. Hillis and C. Moritz), pp. 250-317. Sinauer Associates, Sunderland, Massachusetts.

4. Nei, M. and W.-H. Li. 1979. Mathematical model for studying genetic variation in terms of restriction endonucleases. Proc. Natl. Acad. Sci. 76: 5269-5273.

5. Upholt, W.B. 1977. Estimation of DNA sequence divergence form comparison of restriction endonuclease digests. Nucleic Acids Res. 4: 1257-1265.

6. Cann, R.L. and A.C. Wilson. 1983. Length mutations in human mitochondrial DNA. Genetics 104: 699-711.

7. Ausubel, F.M., ed. 1989. Current protocols in molecular biology. Wiley, New York.

8. Saiki, R.K., D.H. Gelfand, S. Stoffel, S.J. Scharf, R. Higuchi, G.T. Horn, K.B. Mullis, and H.A. Erlich. 1987. Primer-directed enzymatic amplification of DNA with a thermostable DNA polymerase. Science 239: 487-491.

9. Cherfas, J. 1989. Science gives ivory a sense of identity. Science 246: 1120-1121.
10. Kocher, T.D., W.K. Thomas, A. Meyer, S.V. Edwards, S. Pääbo, F.X. Villablanca, and A.C. Wilson. 1989. Dynamics of mitochondrial DNA evolution in animals: Amplification and sequencing with conserved primers. Proc. Natl. Acad. Sci. 86: 6196-6200.

11. Pääbo, S. 1989. Ancient DNA: Extraction, characterization, molecular cloning, and enzymatic amplification. Proc. Natl. Acad. Sci. 86: 1939-1943.

12. Beck, S., T. O'Keeffe, J.M. Coull, and H. Köster. 1989. Chemiluminescent detection of DNA: Application for DNA sequencing and hybridization. Nucleic Acids Res. 17: 5115-5123.

13. Morales, J.C. 1992. "Molecular systematics of the tree bats (genus Lasiurus)." Ph. D. Dissertation. Texas A\&M University, College Station, Texas. $\mathrm{x}+89 \mathrm{pp}$.

14. Maniatis, T., E.F. Fristch, and J. Sambrook. 1982. Molecular cloning: A laboratory manual. Cold Spring Harbor Laboratory Press, Cold Spring Harbor, New York.

15. Zink, R.M. 1991. The geography of mitochondrial DNA variation in two sympatric sparrows. Evolution 45: 329-339.

16. Nei, M. 1987. Molecular evolutionary genetics. Columbia University Press, New York.

17. Allard, M.W. and R.L. Honeycutt. 1992. Nucleotide sequence variation in the mitochondrial 12S rRNA gene and the phylogeny of african mole-rats (Rodentia: Bathyergidae). Mol. Biol. Evol. 9: 27-40.

Received July 17, 1992; accepted in revised form September 25, 1992. 


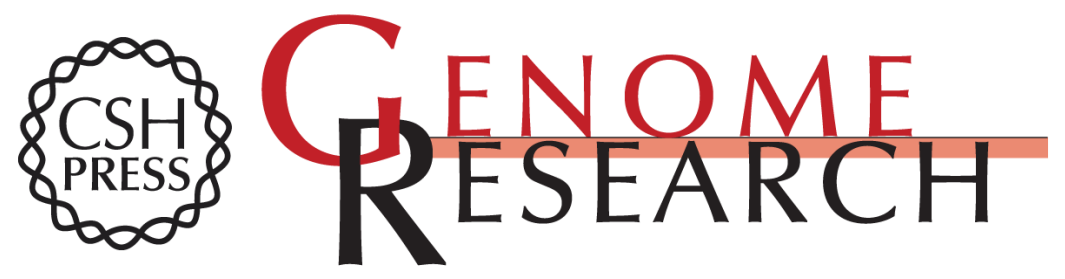

\section{Partial endonuclease digestion mapping of restriction sites using PCR-amplified DNA.}

J C Morales, J C Patton and J W Bickham

Genome Res. 1993 2: 228-233

Access the most recent version at doi:10.1101/gr.2.3.228

References This article cites 11 articles, 4 of which can be accessed free at:

http://genome.cshlp.org/content/2/3/228.full.html\#ref-list-1

\section{License}

Email Alerting Receive free email alerts when new articles cite this article - sign up in the box at the Service top right corner of the article or click here.

\section{Affordable, Accurate Sequencing.}

To subscribe to Genome Research go to:

https://genome.cshlp.org/subscriptions 